\title{
Molecular characterization of tumors from a transgenic mouse adrenal tumor model: Comparison with human pheochromocytoma
}

\author{
YOSHIYUKI HATTORI ${ }^{1}$, NAOTETSU KANAMOTO ${ }^{2}$, KUMI KAWANO $^{1}$, HIROSHI IWAKURA $^{3}$, \\ MASAKATSU SONE ${ }^{2}$, MASAKO MIURA ${ }^{2}$, AKIHIRO YASODA ${ }^{2}$, NAOHISA TAMURA ${ }^{2}$, \\ HIROSHI ARAI $^{2}$, TAKASHI AKAMIZU ${ }^{3}$, KAZUWA NAKAO ${ }^{2}$ and YOSHIE MAITANI $^{1}$ \\ ${ }^{1}$ Institute of Medicinal Chemistry, Hoshi University, Shinagawa-ku, Tokyo 142-8501; ${ }^{2}$ Department of Medicine and \\ Clinical Science, Kyoto University Graduate School of Medicine, Kyoto 606-8507; ${ }^{3}$ Ghrelin Research Project, \\ Translational Research Center, Kyoto University Hospital, Kyoto 606-8507, Japan
}

Received May 3, 2010; Accepted June 21, 2010

DOI: 10.3892/ijo_00000719

\begin{abstract}
Adrenal neuroblastoma and pheochromocytoma have the same embryonic origin from neural crest cells and mainly arise from the adrenal medulla. Recently, transgenic mice exhibiting tumors in the bilateral adrenal medulla by the expression of SV40 T-antigen were developed. In this study, we investigated mRNA expression in adrenal tumors of transgenic mice and compared them with human pheochromocytoma by DNA microarray analysis. To compare mouse adrenal tumors and human pheochromacytoma, we found that the expressions of noradrenergic neuron-related genes, including dopa decarboxylase, phenylethanolamine$\mathrm{N}$-methyltransferase and chromogranin B, were up-regulated in humans but not in mice; however, the expression of neuroblastoma-related genes, including Mycn, paired-like homeobox $2 \mathrm{~b}, \gamma$-aminobutyric acid A receptor $B 3$ subunit, islet 1 and kinesin family member 1A, was up-regulated in both species. From the gene expression profiles, the characterization of mouse adrenal tumor, may be similar to that of human adrenal neuroblastoma rather than pheochromacytomas. This mouse model would be a useful tool for the development of anticancer drugs and for understanding the etiology of adrenal neuroblastoma.
\end{abstract}

\section{Introduction}

Adrenal neuroblastoma and pheochromocytoma have the same embryonic origin from neural crest cells and mainly arise

Correspondence to: Dr Yoshiyuki Hattori, Institute of Medicinal Chemistry, Hoshi University, Shinagawa-ku, Tokyo 142-8501, Japan E-mail: yhattori@hoshi.ac.jp

Key words: adrenal tumor, pheochromocytoma, neuroblastoma, DNA array from the adrenal medulla. Adrenal neuroblastoma is the most common and deadly extracranial solid childhood tumor, exhibiting marked variation in clinical presentation, ranging from localized to high metastatic disease. Neuroblastoma causes $15 \%$ of cancer-related deaths in children (1). Patients with early-stage neuroblastoma, particularly those detected by a mass screening program, are known to have a good prognosis, and the tumors of these patients possess the ability to differentiate and regress spontaneously (2). In contrast, patients with advanced-stage neuroblastoma still have a poor prognosis despite recent developments in treatment (1). Pheochromocytomas are catecholamine-producing tumors that occur from chromaffin cells of adrenal medulla or extra-adrenal location, leading to paroxysmal or persistent hyper-tension in most patients $(3,4)$. Pheochromocytoma generally occurs as a benign tumor, but $10-25 \%$ of cases are malignant at first surgery or at recurrence, with metastasis development in the lymph nodes, bone, liver or lung. Once pheochromocytoma has metastasized, there is no curative therapy; therefore, the availability of reliable tumor models for adrenal neuroblastoma and pheochromocytoma to test novel chemotherapeutic agents remains an important aspect to improve survival.

For the development of new therapeutic drugs for tumors of the adrenal medulla, in vivo rodent models are useful in addition to in vitro cultured tumor cells. In the early 1990s, adrenal medullary neoplasms were reported in transgenic mice carrying simian virus 40 (SV40) or polyoma viral T-antigens driven by a variety of promoters (5-8), including those for tyrosine hydroxylase (Th) (8) and phenylethanolamine $\mathrm{N}$ methyltransferase (Pnmt) (6). Some were classified as primitive neuroectodermal tumors (9) or neuroblastoma (5). Better differentiated pheochromocytomas and hyperplastic nodules have subsequently been reported to occur with high frequency in transgenic mice expressing c-mos $(10,11)$ or multiple endocrine neoplasia (MEN) 2B-type mutant rearranged during transfection (RET) (Met 918) (12) and in retinoblastoma (Rb) (13), phosphatase and tensin homolog deleted from chromosome (Pten) (14) or neurofibromatosis 1 (Nf1) (15) knockout mice. Unfortunately, some of these mice have not 
been maintained and may be permanently lost as experimental models.

Recently, we developed transgenic mice exhibiting tumors in the bilateral adrenal glands by the expression of SV40 T-antigen and have maintained them as a experimental model (16). Genome-wide gene expression studies will provide insight into the genes and molecular pathways that govern the pathogenesis of adrenal tumors; however, this has not been reported in adrenal tumor model mice. In this study, we investigated mRNA expression in adrenal tumors of transgenic mice and compared them with human pheochromocytoma by DNA microarray analysis.

\section{Materials and methods}

Animals. Transgenic mice carrying tetracycline inducible SV40 T-antigen, a fusion gene comprising tetracycline-responsive elements (TRE) with cytomegarovirus promoter and SV40 $\mathrm{T}$-antigen were generated by microinjection of fertilized C57/B6 mouse eggs as previously reported (16). Transgenic mice were used as heterozygotes. Animal experiments were conducted with ethics approval from our institutional animal care and use committee.

Histopathology. Excised adrenal tumors from transgenic mice at the age of 5, 9, 13, 15, 17 and 21 weeks $(5 \mathrm{~T}, 9 \mathrm{~T}, 13 \mathrm{~T}, 15 \mathrm{~T}$, $17 \mathrm{~T}$ and $21 \mathrm{~T}$, respectively) and normal adrenal gland from non-transgenic littermates at the age of 5, 9, 13 and 17 weeks $(5 \mathrm{~N}, 9 \mathrm{~N}, 13 \mathrm{~N}$ and $17 \mathrm{~N}$, respectively) were immediately frozen, sectioned $20-\mu \mathrm{m}$ thick and mounted. The sections were stained with hematoxylin and pure eosin (H\&E staining) (Muto Pure Chemicals Co., Ltd., Tokyo, Japan) for histopathological examination.

Tumor procurement. Human tumor specimens were collected from patients who underwent surgery at Kyoto University Hospital (Kyoto, Japan). Specimens were procured under Institutional Review Board-approved protocols compliant with international guidelines and with informed consent from patients. Tumor samples and normal adjacent samples were frozen and stored at $-80^{\circ} \mathrm{C}$ shortly after surgical resection. Total RNA was extracted from tumors using an RNeasy Midi Kit (Qiagen, Hilden, Germany). The quality and quantity of RNA were sufficient for gene expression profiling in 7 pheochromocytoma and 2 normal adjacent adrenal medulla from 2 patients with pheochromocytoma.

RT-PCR analysis. Total RNA was isolated from mouse adrenal tumors using the RNeasy Midi Kit (Qiagen). RNA yield and purity were checked by spectrometric measurements at 260 and $280 \mathrm{~nm}$, and RNA electrophoresis, respectively. RT-PCR amplification was carried out as previously reported (17). The profile of PCR amplification consisted of denaturation at $94^{\circ} \mathrm{C}$ for $0.5 \mathrm{~min}$, primer annealing at $55^{\circ} \mathrm{C}$ for $0.5 \mathrm{~min}$, and elongation at $72^{\circ} \mathrm{C}$ for $0.5 \mathrm{~min}$ for 30 cycles. For the amplification of SV40 T-antigen cDNA, the primers SV40 T-antigen-FW, 5'-AAACACTGCAGGCCAGATTT-3', and SV40 T-antigen-RW, 5'-AAATGAGCCTTGGGACTGTG-3', were used. For the amplification of mouse $\beta$-actin cDNA, the primers $B$-actin-FW, 5'-TGTGATGGTGGGAATGGGT
CAG-3', and ß-actin-RW, 5'-TTTGATGTCACGCACGATT TCC-3', were used. PCR products were analyzed by $1.5 \%$ agarose gel electrophoresis in a Tris-borate-EDTA (TBE) buffer. The products were visualized by ethidium bromide staining.

Real-time RT-PCR was performed on the corresponding cDNA synthesized from each sample described above. The optimized settings were transferred to the real-time PCR protocol with the iCycler MyiQ detection system (Bio-Rad Laboratories, Hercules, CA, USA) and SYBR Green I assay (iQ $^{\text {TM }}$ SYBER Green Supermix, Bio-Rad Laboratories) was used for quantification. Samples were run in triplicate and the expression level of each mRNA was normalized for the amount of $B$-actin in the same sample. Difference of 1 cycle was calculated as a 2 -fold-change in the gene expression.

DNA microarray. For DNA microarray experiments, $0.5 \mu \mathrm{g}$ aliquots of total RNA from 13N, 13T, 15T, 17T and human tumor specimens were labeled using the Quick Amp Labeling Kit (Agilent Technologies, Santa Clara, CA, USA) according to the manufacturer's instructions. After purification of Cy3labeled cRNA with RNeasy mini spin columns (Qiagen), $1.65 \mu \mathrm{g}$ aliquots of Cy3-labeled cRNA were hybridized to Whole Mouse genome Oligo Microarray 44K x 4 (Agilent Technologies) or Whole Human genome Oligo Microarray 44K x 4 (Agilent Technologies) using the manufacturer's hybridization protocol. After the washing step, the microarray slides were analyzed with an Agilent Technologies Microarray scanner.

For further analysis, the data were imported into the GeneSpring ${ }^{\circledR} 10$ Software (Agilent Technologies) and normalized by median centering of arrays and genes. In mouse adrenal tumors, all transcripts showed a minimum change in the expression level of at least 10-fold compared with the adrenal gland of normal mice. In a comparison of the expression profiles between mouse and human adrenal tumors, hierarchical clustering of the above identified genes in mouse adrenal tumor and image plots using available human orthologues in pheochromocytoma were displayed with gene ordering based on hierarchical clustering of the mouse data set.

\section{Results}

Tumor appearance and SV40 T-antigen expression. We previously reported that the ectopic expression of SV40 T-antigen in adrenal medulla developed bilateral adrenal tumors at 1213 weeks of age in mice (16). In hematoxylin and eosin-stained sections of adrenal glands, mild hyperplasia in the adrenal medulla of transgenic mice was already observed at 5 and 9 weeks of age (Fig. 1A, B, E and F). Subsequently, transgenic mice, beginning at 13 weeks of the age, developed carcinoma of the adrenal gland (Figs. 1I, J and 2A), and by 15 weeks of age, most adrenal tumors were between 0.5 and $1.0 \mathrm{~cm}$ in diameter (Fig. 2A). At 17 weeks of the age, tumors of the adrenal glands had enlarged to $1.0-1.5 \mathrm{~cm}$ diameter, and at 21 weeks of age, to $1.5-2.0 \mathrm{~cm}$. The tumors in $17 \mathrm{~T}$ were composed of undifferentiated cells with a large nucleus (Fig. 1M and N) compared with adrenal glands in non-transgenic mice.

Next, we confirmed the expression levels of SV40 Tantigen mRNA in the developing tumors of transgenic mice. 

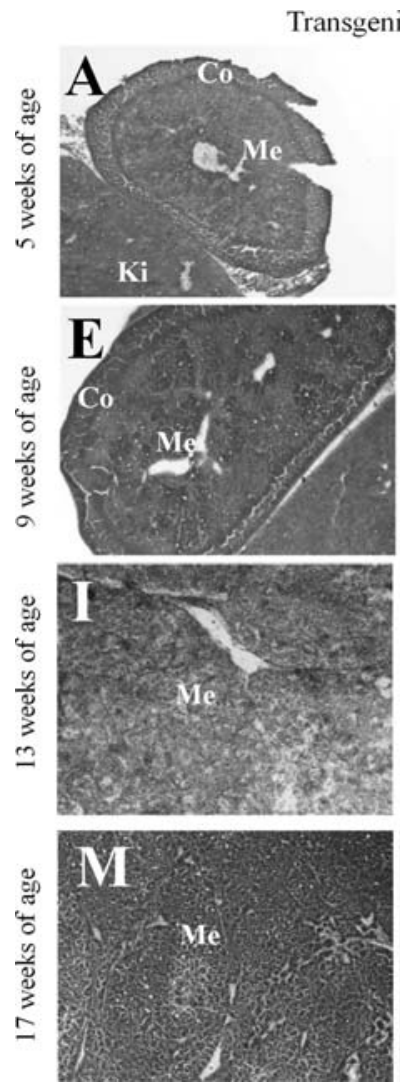
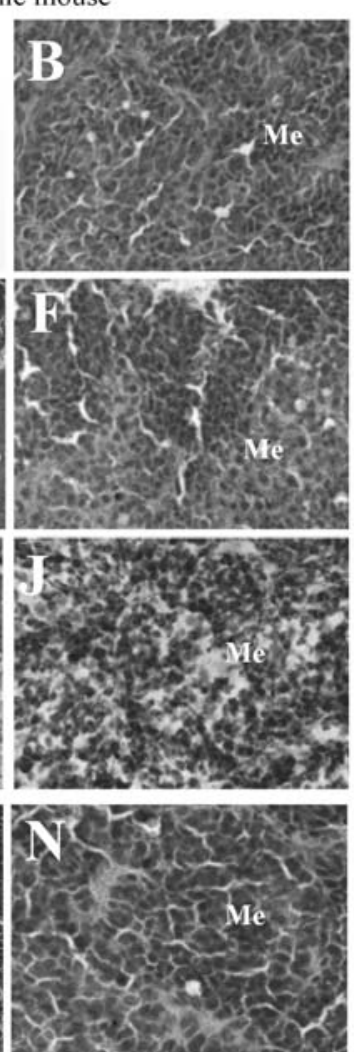

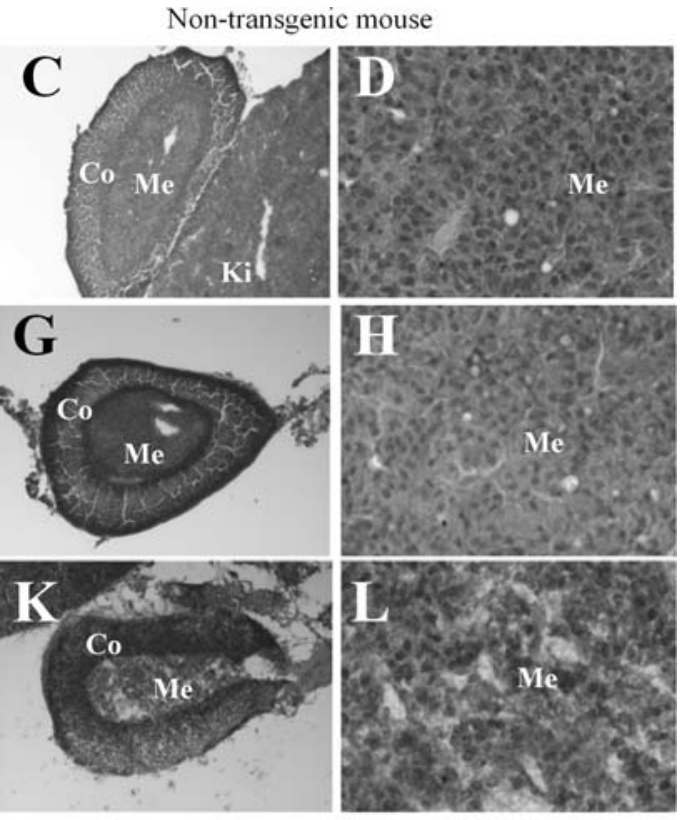

Figure 1. Histological analysis of adrenal gland from transgenic mouse. Histological section of adrenal gland from transgenic mice (A, B, E, F, I, J, M and N) and non-transgenic (C, D, G, H, K and L) mice at 5 weeks (A-D), 9 weeks (E-H), 13 weeks (I-L) and 17 weeks of age (M and N). In B, D, F, H, J, L and N, adrenal medulla in A, C, E, G, I, K and M were enlarged, respectively. H\&E staining, x40 in A, C, E, G, I, K and M, x100 in B, D, F, H, J, L and N. Co, cortex of adrenal gland; Me, medulla of adrenal gland; Ki, kidney.

A

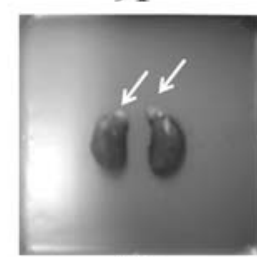

$9 \mathbf{N}$

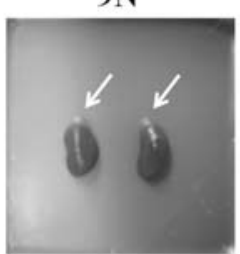

B


$17 \mathbf{T}$
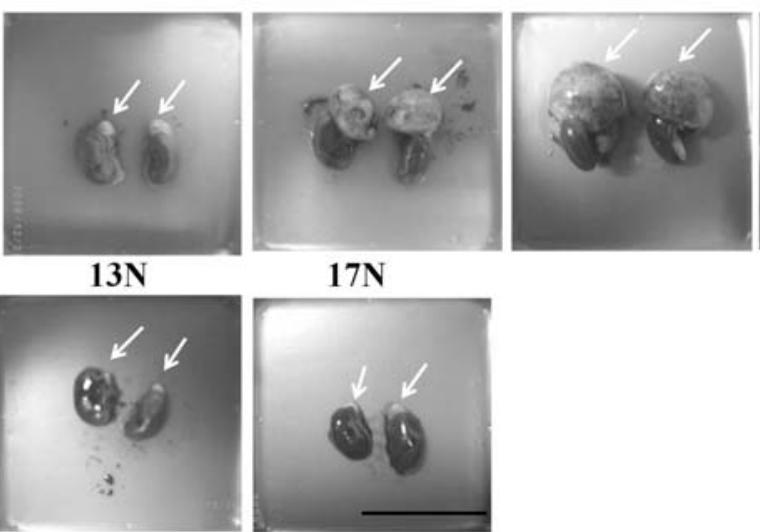

$13 N$
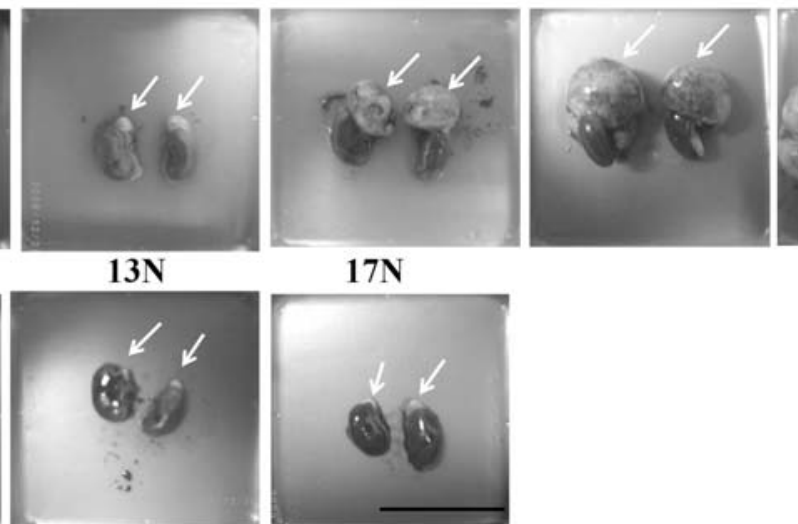

$21 \mathrm{~T}$

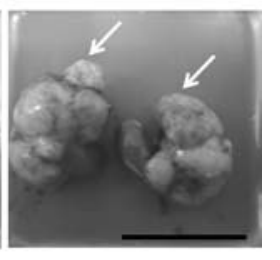

Scale bar $=2 \mathrm{~cm}$

Figure 2. Gross appearance (A) and expression of SV40 T-antigen mRNA (B) of adrenal gland from transgenic mouse. Adrenal tumors from transgenic mouse at ages of 5, 9, 13,15, 17 and 21 weeks $(5 \mathrm{~T}, 9 \mathrm{~T}, 13 \mathrm{~T}, 15 \mathrm{~T}, 17 \mathrm{~T}$ and $21 \mathrm{~T}$, respectively) and adrenal glands from non-transgenic littermates at ages of $5,9,13$ and 17 weeks $(5 \mathrm{~N}, 9 \mathrm{~N}, 13 \mathrm{~N}$ and $17 \mathrm{~N}$, respectively) were excised. In (A), arrows indicated adrenal tumor or adrenal gland. In (B), expression of SV40 T-antigen mRNA was analyzed by quantitative RT-PCR. The expression level of SV40 T-antigen mRNA was normalized for the amount of $\beta$-actin in the same sample. Each result represents the mean $\pm S D(n=3)$. $\mathrm{ND}$, not detected. 


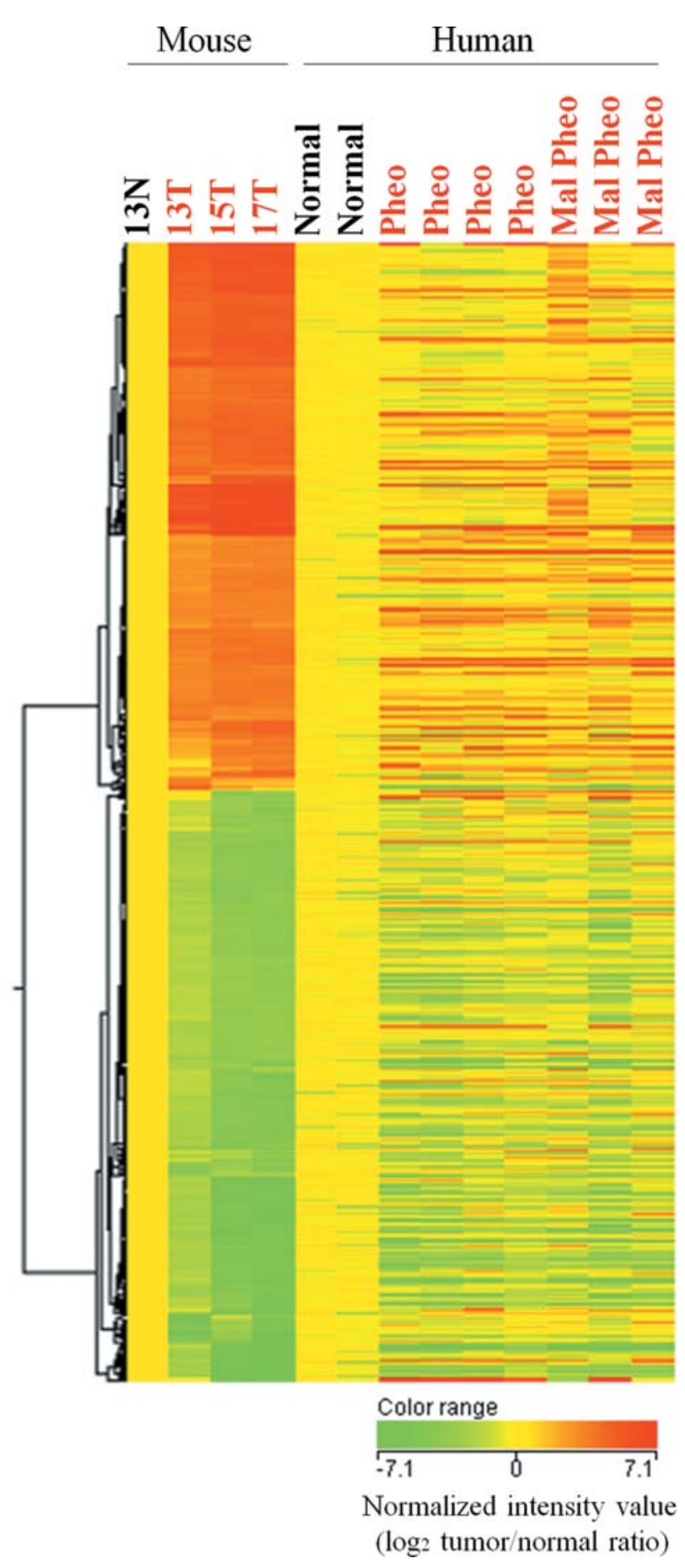

Figure 3. Gene expression patterns of mouse adrenal tumor-specific signature in human pheochromocytoma. Hierarchical clustering of mouse adrenal tumors $(13 \mathrm{~T}, 15 \mathrm{~T}$ and $17 \mathrm{~T})$-specific genes ( 2,500 genes), which were $>10$-fold higher and lower than in the normal adrenal gland $(13 \mathrm{~N})$, and image plots using available human orthologues in pheochromocytoma are shown with gene ordering based on hierarchical clustering of the mouse data set. Expression profiles in four benign pheochromocytomas (Pheo), three malignant pheochromocytomas (Mal Pheo) and two normal adjacent adrenal medulla (normal) were aligned beside those in mouse tumors. Genes with a relatively higher level of expression are shown in red and those with a lower level of expression in green.

Expression levels of SV40 T-antigen from 5T to $17 \mathrm{~T}$ were similar, but those in $5 \mathrm{~N}$ and $13 \mathrm{~N}$ were not detected (Fig. 2B), suggesting that SV40 T-antigen was expressed in adrenal glands of transgenic mice at an early age and induced adrenal hyperplasia.

Comparison of gene expression patterns between mouse adrenal tumor and human pheochromocytoma. Cells of adrenal neuroblastomas have neuroblastic morphology and do not express the adrenal chromaffin marker Pmnt, but they share phenotypic characteristics with immature sympathetic neuroblasts present as nests of cells in the developing adrenal gland (18). Although sympathetic neurons and chromaffin cells are developmentally related and functionally similar, a defining functional difference between the two cell types is that only chromaffin cells express Pmnt (18).

We compared the expression profile of transgenic mice with that of human pheochromocytoma by DNA microarray (Fig. 3). To investigate mRNA expression in developing adrenal tumors of transgenic mice, we used RNA of adrenal tumors from $13 \mathrm{~T}, 15 \mathrm{~T}$ and $17 \mathrm{~T}$, and of the normal adrenal gland from $13 \mathrm{~N}$ as a control. Overall, the expression patterns of up- and down-regulated genes in both human benign and malignant pheochromocytomas were similar with those in mouse adrenal tumors (Fig. 3). Furthermore, the expression profile in benign pheochromocytomas was very similar to that in malignant pheochromocytomas, therefore, in subsequent analysis, we used average of four benign and three malignant pheochromocytomas for comparison of expression level with mouse adrenal tumors. In adrenal tumors of transgenic mice, Pmnt expression was absent and other noradrenergic synthesisrelated genes also greatly reduced compared with in normal adrenal gland, although up-regulated in human pheochromacytoma (Table I). It has been reported that Pmnt expression was absent or greatly reduced in tumors associated with viral T-antigens $(8,19)$. Furthermore, no difference in blood pressure between transgenic and non-transgenic mice was observed ( $\sim 60 \mathrm{mmHg}$ in mean blood pressure) (data not shown). These findings indicated that the characteristics of human pheochromocytoma regarding noradrenergic secretion and hypertension were dissimilar to those of mouse adrenal tumors.

Recently, Cheung et al have reported that cyclin D1 (CCND1), dopa decarboxylase (DDC), $\gamma$-aminobutyric acid A receptor B3 subunit (GABRB3), islet 1 (ISL1), kinesin family member 1A (KIF1A), and paired-like homeobox 2b (PHOX2B) were abundantly expressed in stage IV human neuroblastoma tumors and these expressions were useful in predicting patient outcome (20). In both mouse and human adrenal tumors, Phox2b, Gabrb3, Isl1 and Kif1a were also up-regulated (Table I). Furthermore, we found 49 up-regulated genes and 66 down-regulated genes which were $>10$-fold different between a normal adrenal gland and the adrenal tumor in both mice and humans (Tables II and III). Among them, we found that the expressions of doublecortin and CaM kinaselike 1 (Dclk1), dihydropyrimidinase-like 3 (Dpysl3), embryonic lethal, abnormal vision, Drosophila-like 3 (Elav13), GATA binding protein 2 (Gata2), GATA binding protein 3 (Gata3), hairy/enhancer-of-split related with YRPW motif 1 (Hay1), myelin transcription factor 1-like (Myt11), transgelin 3 (Tagln3), and transcription factor AP-2 B (Tcfap2b), which are related to nervous system development, were strongly upregulated in both human and mouse adrenal tumors (Table II), and the expression of many genes related to lipid metabolic 
Table I. Adrenal gland-related genes in human pheochromocytoma and mouse adrenal tumors as shown by cDNA microarray.

\begin{tabular}{|c|c|c|c|c|c|c|}
\hline \multirow[b]{2}{*}{$\begin{array}{l}\text { Gene } \\
\text { symbol }\end{array}$} & \multirow[b]{2}{*}{ Description } & \multicolumn{4}{|c|}{ Gene expression ( $\log _{2}$ tumor/normal ratio) } & \multirow[b]{2}{*}{ Biological process } \\
\hline & & $13 \mathrm{~T} / 13 \mathrm{~N}$ & $15 \mathrm{~T} / 13 \mathrm{~N}$ & $17 \mathrm{~T} / 13 \mathrm{~N}$ & $\begin{array}{l}\text { Pheo/ } \\
\text { normal }\end{array}$ & \\
\hline \multicolumn{7}{|c|}{ Noradrenergic neuron-related genes } \\
\hline Ddc & Dopa decarboxylase & 0.64 & -3.11 & -1.14 & 7.91 & $\begin{array}{l}\text { Catecholamine biosynthetic } \\
\text { process }\end{array}$ \\
\hline $\mathrm{Th}$ & Tyrosine hydroxylase & 1.06 & 0.16 & -0.30 & 7.91 & $\begin{array}{l}\text { Dopamine biosynthetic process } \\
\text { from tyrosine }\end{array}$ \\
\hline Dbh & Dopamine $\beta$ hydroxylase & 1.20 & 1.33 & 0.89 & 7.33 & $\begin{array}{l}\text { Catecholamine metabolic } \\
\text { process }\end{array}$ \\
\hline Pnmt & $\begin{array}{l}\text { Phenylethanolamine-N- } \\
\text { methyltransferase }\end{array}$ & -0.08 & -6.33 & -8.53 & 6.10 & $\begin{array}{l}\text { Catecholamine biosynthetic } \\
\text { process }\end{array}$ \\
\hline Chga & Chromogranin A & 0.17 & 0.09 & -0.18 & 7.80 & \\
\hline Chgb & Chromogranin B & -0.24 & -0.21 & -0.06 & 5.96 & \\
\hline Npy & Neuropeptide Y & -0.08 & -0.50 & -0.70 & 7.39 & Neuropeptide signaling pathway \\
\hline Slc6a2 & $\begin{array}{l}\text { Solute carrier family } 6 \text {, } \\
\text { member } 2\end{array}$ & 2.47 & 1.25 & 0.28 & 7.99 & Neurotransmitter transport \\
\hline \multicolumn{7}{|c|}{ Neuroblastoma-related genes } \\
\hline Phox $2 b$ & Paired-like homeobox $2 b$ & 1.49 & 1.86 & 1.94 & 9.04 & Regulation of transcription \\
\hline Mycn & $\begin{array}{l}\text { V-myc myelocytomatosis } \\
\text { viral related oncogene, } \\
\text { neuroblastoma derived }\end{array}$ & 0.76 & 0.97 & 1.47 & 5.79 & $\begin{array}{l}\text { Regulation of progression } \\
\text { through cell cycle }\end{array}$ \\
\hline Ccnd1 & Cyclin D1 & -1.97 & -3.11 & -3.42 & 0.67 & $\begin{array}{l}\text { Regulation of progression } \\
\text { through cell cycle }\end{array}$ \\
\hline Crmp1 & $\begin{array}{l}\text { Collapsin response mediator } \\
\text { protein } 1\end{array}$ & 2.74 & 3.34 & 3.27 & 6.19 & \\
\hline Gabrb3 & $\begin{array}{l}\gamma \text {-aminobutyric acid } \\
\text { receptor, subunit } \beta 3\end{array}$ & 2.98 & 2.82 & 2.64 & 4.45 & $\begin{array}{l}\gamma \text {-aminobutyric acid signaling } \\
\text { pathway }\end{array}$ \\
\hline Isl1 & $\begin{array}{l}\text { ISL1 transcription factor, } \\
\text { LIM/homeodomain }\end{array}$ & 4.24 & 5.99 & 6.17 & 4.36 & Regulation of transcription \\
\hline Kif1a & Kinesin family member $1 \mathrm{~A}$ & 0.48 & 1.50 & 1.61 & 6.17 & Microtubule-based process \\
\hline
\end{tabular}

Pheo, human pheochromocytoma; normal, human normal adrenal medulla.

process and electron transport was strongly down-regulated (Table III). The reasons for suppression of the metabolism might be that energy (ATP) in tumor cells is mainly or only provided by glycolysis in the cytoplasm and suppresses oxidative phosphorylation in mitochondria (Warburg effect) (21).

We also found that $G$ protein-regulated inducer of neurite outgrowth 1 (Grin1) (22), insulin-like growth factor 2 gene (Igf2) (23), embryonic lethal, abnormal vision, Drosophilalike 4 (Elav14) (24), and cadherin-like 22 (Cdh22) (25), which are known to relate with neuroblastoma progression, were strongly up-regulated in both mouse and human adrenal tumors (Table II). These identified genes might be important for the development of adrenal tumors in mice and humans. From gene expression profiles, the characterization of mouse adrenal tumor might be similar to that of human adrenal neuroblastoma rather than pheochromacytoma.

\section{Discussion}

In this study, we investigated mRNA expression in adrenal tumors of transgenic mice carrying SV40 T-antigen by DNA microarray analysis. The SV40 T-antigen oncoprotein binds to and functionally inactivates two major tumor suppressor genes, $\mathrm{Rb}$ and p53, which are often involved in many human tumors, and strongly affects many genes associated with DNA replication, damage repair, cytokinesis, and chromosome maintenance. It has been reported that proliferative gene expression patterns driven by the SV40 T-antigen were shared by transgenic mice carrying SV40 T-antigen, which 
Table II. The highly up-regulated (>10-fold) genes both in human pheochromocytoma and mouse adrenal tumor (17T) as shown by cDNA microarray.

\begin{tabular}{|c|c|c|c|c|c|c|}
\hline \multirow[b]{2}{*}{$\begin{array}{l}\text { Gene } \\
\text { symbol }\end{array}$} & \multirow[b]{2}{*}{ Description } & \multicolumn{4}{|c|}{ Gene expression ( $\log _{2}$ tumor/normal ratio) } & \multirow[b]{2}{*}{ Biological process } \\
\hline & & $13 \mathrm{~T} / 13 \mathrm{~N}$ & $15 \mathrm{~T} / 13 \mathrm{~N}$ & $17 \mathrm{~T} / 13 \mathrm{~N}$ & $\begin{array}{l}\text { Pheo/ } \\
\text { normal }\end{array}$ & \\
\hline A2bp1 & Ataxin 2-binding protein 1 & 3.02 & 3.72 & 3.45 & 3.45 & \\
\hline Abcc8 & $\begin{array}{l}\text { ATP-binding cassette, sub- } \\
\text { family } C \text {, member } 8\end{array}$ & 3.54 & 4.94 & 4.93 & 4.64 & Carbohydrate metabolic process \\
\hline Bai3 & $\begin{array}{l}\text { Brain-specific angiogenesis } \\
\text { inhibitor } 3\end{array}$ & 4.23 & 5.11 & 5.17 & 4.23 & Signal transduction \\
\hline Cartpt & CART prepropeptide & 6.52 & 6.56 & 5.83 & 6.21 & Neuropeptide signaling pathway \\
\hline $\operatorname{Cdh} 22$ & Cadherin-like 22 & 3.06 & 3.72 & 3.52 & 7.70 & Cell adhesion \\
\hline Celsr3 & $\begin{array}{l}\text { Cadherin, EGF LAG seven- } \\
\text { pass G-type receptor } 3\end{array}$ & 3.31 & 3.54 & 3.54 & 5.74 & Neuropeptide signaling pathway \\
\hline Chrm2 & $\begin{array}{l}\text { Cholinergic receptor, } \\
\text { muscarinic } 2\end{array}$ & -0.29 & 2.94 & 3.38 & 3.45 & Signal transduction \\
\hline Chrna5 & $\begin{array}{l}\text { Cholinergic receptor, } \\
\text { nicotinic, } \alpha 5\end{array}$ & 3.55 & 3.65 & 3.96 & 3.46 & Signal transduction \\
\hline Clgn & Calmegin & 5.16 & 6.18 & 6.40 & 7.56 & Protein folding \\
\hline Coro2a & $\begin{array}{l}\text { Coronin, actin binding } \\
\text { protein, } 2 \mathrm{~A}\end{array}$ & 3.22 & 3.65 & 3.43 & 3.95 & \\
\hline Crtac1 & Cartilage acidic protein 1 & 5.25 & 6.00 & 5.99 & 3.79 & \\
\hline Cryba2 & Crystallin, $B \mathrm{~A} 2$ & 4.42 & 4.53 & 5.02 & 7.99 & \\
\hline Dclk1 & $\begin{array}{l}\text { Doublecortin and CaM } \\
\text { kinase-like } 1\end{array}$ & 4.57 & 6.38 & 6.83 & 5.93 & Nervous system development \\
\hline Dpysl3 & Dihydropyrimidinase-like 3 & 2.66 & 4.26 & 4.64 & 3.90 & Nervous system development \\
\hline Elavl3 & ELAV-like 3 & 4.48 & 5.20 & 5.31 & 4.01 & Nervous system development \\
\hline Elavl4 & ELAV-like 4 & 5.01 & 6.07 & 5.90 & 6.22 & mRNA processing \\
\hline Elavl4 & $\begin{array}{l}\text { Elongation of very long } \\
\text { chain fatty acids-like } 4\end{array}$ & 5.64 & 6.05 & 5.85 & 3.87 & Fatty acid biosynthetic process \\
\hline Erc2 & $\begin{array}{l}\text { ELKS/RAB6-interacting/ } \\
\text { CAST family member } 2\end{array}$ & 4.07 & 3.75 & 3.90 & 3.89 & Synaptogenesis \\
\hline Flrt1 & $\begin{array}{l}\text { Fibronectin leucine rich } \\
\text { transmembrane protein } 1\end{array}$ & 3.46 & 3.22 & 3.56 & 5.53 & \\
\hline Galnt6 & $\begin{array}{l}\text { UDP-N-acetyl- } \alpha-\mathrm{D} \text { - } \\
\text { galactosamine: polypeptide } \\
\text { N-acetylgalactosaminyl } \\
\text { transferase } 6\end{array}$ & 4.21 & 4.75 & 4.23 & 3.78 & $\begin{array}{l}\text { Protein amino acid O-linked } \\
\text { glycosylation }\end{array}$ \\
\hline Gata2 & GATA binding protein 2 & 4.27 & 3.91 & 4.02 & 5.50 & Neuron differentiation \\
\hline Gata3 & GATA binding protein 3 & 3.46 & 3.89 & 3.87 & 4.87 & Nervous system development \\
\hline Gpr68 & $\begin{array}{l}\text { G protein-coupled } \\
\text { receptor } 68\end{array}$ & 4.02 & 4.98 & 4.53 & 4.07 & Signal transduction \\
\hline Gprin1 & $\begin{array}{l}\text { G protein regulated inducer } \\
\text { of neurite outgrowth } 1\end{array}$ & 3.43 & 3.98 & 3.83 & 4.38 & \\
\hline Hand1 & $\begin{array}{l}\text { Heart and neural crest } \\
\text { derivatives expressed } 1\end{array}$ & 5.04 & 4.99 & 4.70 & 4.36 & Angiogenesis \\
\hline Hey1 & $\begin{array}{l}\text { Hairy/enhancer-of-split } \\
\text { related with YRPW motif } 1\end{array}$ & 3.43 & 3.84 & 4.21 & 4.79 & Nervous system development \\
\hline Igf2 & Insulin-like growth factor 2 & 3.87 & 2.60 & 3.34 & 3.55 & Cell proliferation \\
\hline Isl1 & $\begin{array}{l}\text { ISL1 transcription factor, } \\
\text { LIM/homeodomain }\end{array}$ & 4.24 & 5.99 & 6.17 & 4.36 & $\begin{array}{l}\text { Multicellular organismal } \\
\text { development }\end{array}$ \\
\hline
\end{tabular}


Table II. Continued.

\begin{tabular}{|c|c|c|c|c|c|c|}
\hline \multirow[b]{2}{*}{$\begin{array}{l}\text { Gene } \\
\text { symbol }\end{array}$} & \multirow[b]{2}{*}{ Description } & \multicolumn{4}{|c|}{ Gene expression ( $\log _{2}$ tumor/normal ratio) } & \multirow[b]{2}{*}{ Biological process } \\
\hline & & $13 \mathrm{~T} / 13 \mathrm{~N}$ & $15 \mathrm{~T} / 13 \mathrm{~N}$ & $17 \mathrm{~T} / 13 \mathrm{~N}$ & $\begin{array}{l}\text { Pheo/ } \\
\text { normal }\end{array}$ & \\
\hline Kcnj12 & $\begin{array}{l}\text { Potassium inwardly- } \\
\text { rectifying channel, sub- } \\
\text { family J, member } 12\end{array}$ & 3.10 & 3.86 & 3.77 & 3.46 & Ion transport \\
\hline Kif5a & Kinesin family member $5 \mathrm{~A}$ & 3.74 & 4.45 & 4.63 & 3.58 & Microtubule-based movement \\
\hline $\mathrm{K} 1$ & Klotho & 1.29 & 3.56 & 3.75 & 5.34 & Metabolic process \\
\hline Lingo1 & $\begin{array}{l}\text { Eucine rich repeat and } \\
\text { Ig domain containing } 1\end{array}$ & 6.47 & 6.63 & 6.53 & 4.59 & \\
\hline Lmo1 & LIM domain only 1 & 3.06 & 4.47 & 4.23 & 5.33 & Cell proliferation \\
\hline Mab2111 & Mab-21-like 1 & 4.67 & 5.23 & 5.05 & 5.14 & $\begin{array}{l}\text { Anatomical structure } \\
\text { morphogenesis }\end{array}$ \\
\hline Mgat5b & $\begin{array}{l}\text { Mannosyl }(\alpha 1,6)- \\
\text { glycoprotein } \beta-1,6-\mathrm{N} \text {-acetyl } \\
\text {-glucosaminyltransferase }\end{array}$ & 2.49 & 3.04 & 3.64 & 3.53 & \\
\hline Myt11 & $\begin{array}{l}\text { Myelin transcription factor } \\
\text { 1-like }\end{array}$ & 3.46 & 3.31 & 3.41 & 3.60 & Nervous system development \\
\hline Nefl & $\begin{array}{l}\text { Neurofilament, light } \\
\text { polypeptide } 68 \mathrm{kDa}\end{array}$ & 4.53 & 6.79 & 6.94 & 8.23 & \\
\hline Prph1 & Peripherin & 4.82 & 6.05 & 6.33 & 7.53 & \\
\hline Rab39b & $\begin{array}{l}\text { RAB39B, member RAS } \\
\text { oncogene family }\end{array}$ & 3.76 & 4.52 & 4.11 & 4.70 & Protein transport \\
\hline Rimbp2 & RIMS binding protein 2 & 3.65 & 4.72 & 4.46 & 5.66 & \\
\hline Slc10a4 & $\begin{array}{l}\text { Solute carrier family } 10 \text {, } \\
\text { member } 4\end{array}$ & 2.46 & 4.01 & 4.01 & 6.92 & Ion transport \\
\hline Stac & $\begin{array}{l}\text { SH3 and cysteine rich } \\
\text { domain }\end{array}$ & 2.13 & 3.66 & 3.60 & 3.74 & Intracellular signaling cascade \\
\hline Stmn4 & Stathmin-like 4 & 5.06 & 6.03 & 5.50 & 5.86 & Intracellular signaling cascade \\
\hline Syt11 & Synaptotagmin XI & 3.66 & 4.13 & 4.25 & 4.59 & Transport \\
\hline Tagln3 & Transgelin 3 & 2.84 & 3.74 & 3.72 & 7.25 & Nervous system development \\
\hline Tcfap $2 b$ & $\begin{array}{l}\text { Transcription factor AP- } 2 B \\
\text { protein } 2\end{array}$ & 5.06 & 5.08 & 5.19 & 7.75 & Nervous system development \\
\hline Thbs4 & Thrombospondin 4 & 3.36 & 6.29 & 6.19 & 4.07 & Cell adhesion \\
\hline Tm6sf2 & $\begin{array}{l}\text { Transmembrane } 6 \\
\text { superfamily member } 2\end{array}$ & -0.10 & 0.93 & 4.49 & 3.48 & \\
\hline Tmem145 & Transmembrane protein 145 & 3.19 & 3.14 & 3.39 & 4.25 & \\
\hline Tubb2b & Tubulin, B 2B & 3.35 & 5.00 & 4.84 & 6.90 & Microtubule-based movement \\
\hline
\end{tabular}

Pheo, human pheochromocytoma; normal, human normal adrenal medulla.

developed breast tumor (C3(1)/Tag transgenic mice driven by rat prostate steroid binding protein promoter), lung tumor (CC10-Tag transgenic mice driven by mouse clara cell secretory protein promoter), and prostate tumor (TRAMP transgenic mouse driven by rat probasin promoter) (26). Therefore, we compared the expression profiles of the SV40 $\mathrm{T}$-antigen signature between adrenal tumors and three tumor types of transgenic mice carrying SV40 T-antigen, and the expression profile of mouse adrenal tumor was very similar to other tumor types of transgenic mouse (data not shown).
The SV40 T-antigen gene signature was not a feature of tumors initiated by other oncogenes or inactivation of suppressor genes but is most specific to tumors induced by T-antigen (26). Transgenic overexpression of myc, ras, HER-2/neu, and polyoma viral middle T-antigen (PyMT) oncogenes driven by mouse mammary tumor virus (MMTV) promoter were most dissimilar to those of SV40 T-antigen in gene expression profiles; however, SV40 T-antigen viral oncoprotein can cause an intrinsic gene expression profile that recapitulates the aggressive phenotypes of aggressive 
Table III. The highly down-regulated (>10-fold) genes both in human pheochromocytoma and mouse adrenal tumor (17T) as shown by cDNA microarray.

\begin{tabular}{|c|c|c|c|c|c|c|}
\hline \multirow[b]{2}{*}{$\begin{array}{l}\text { Gene } \\
\text { symbol }\end{array}$} & \multirow[b]{2}{*}{ Description } & \multicolumn{4}{|c|}{ Gene expression ( $\log _{2}$ tumor/normal ratio) } & \multirow[b]{2}{*}{ Biological process } \\
\hline & & $13 \mathrm{~T} / 13 \mathrm{~N}$ & $15 \mathrm{~T} / 13 \mathrm{~N}$ & $17 \mathrm{~T} / 13 \mathrm{~N}$ & $\begin{array}{l}\text { Pheo/ } \\
\text { normal }\end{array}$ & \\
\hline Aadac & Arylacetamide deacetylase & -6.00 & -3.34 & -6.80 & -9.25 & Metabolic process \\
\hline Abca8b & $\begin{array}{l}\text { ATP-binding cassette, } \\
\text { sub-family A, member } 8\end{array}$ & -1.29 & -2.50 & -3.94 & -3.71 & Transport \\
\hline Abcb1a & $\begin{array}{l}\text { ATP-binding cassette, } \\
\text { sub-family B, member } 1\end{array}$ & -2.15 & -4.34 & -3.98 & -3.56 & Transport \\
\hline Abcb4 & $\begin{array}{l}\text { Homo sapiens ATP-binding } \\
\text { cassette, sub-family B, } \\
\text { member } 4\end{array}$ & -2.60 & -5.65 & -5.95 & -3.95 & Lipid metabolic process \\
\hline Ace2 & $\begin{array}{l}\text { Angiotensin I converting } \\
\text { enzyme } 2\end{array}$ & -1.63 & -3.13 & -5.97 & -4.09 & Proteolysis \\
\hline Adh1 & $\begin{array}{l}\text { Alcohol dehydrogenase } 1 \mathrm{C} \text {, } \\
\gamma \text { polypeptide }\end{array}$ & -1.87 & -5.69 & -7.09 & -3.68 & Alcohol metabolic process \\
\hline Adh4 & $\begin{array}{l}\text { Alcohol dehydrogenase } 4 \text {, } \\
\text { pi polypeptide }\end{array}$ & -4.96 & -2.80 & -4.09 & -4.33 & Alcohol metabolic process \\
\hline Agtr1a & $\begin{array}{l}\text { Angiotensin II receptor, } \\
\text { type } 1\end{array}$ & -2.00 & -5.16 & -5.90 & -3.53 & Signal transduction \\
\hline Alas 1 & $\begin{array}{l}\text { Aminolevulinate, } \Delta \text {, } \\
\text { synthase } 1\end{array}$ & -2.40 & -5.64 & -5.98 & -4.69 & Biosynthetic process \\
\hline Aldh111 & $\begin{array}{l}\text { Aldehyde dehydrogenase } 1 \\
\text { family, member L1 }\end{array}$ & -2.60 & -5.11 & -5.71 & -5.24 & Biosynthetic process \\
\hline Aldob & $\begin{array}{l}\text { Aldolase B, fructose- } \\
\text { bisphosphate }\end{array}$ & -5.84 & -2.99 & -6.61 & -3.87 & Metabolic process \\
\hline Aox 1 & Aldehyde oxidase 1 & -2.47 & -5.25 & -5.28 & -7.73 & Electron transport \\
\hline Apoc1 & Apolipoprotein C-I & -3.17 & -3.52 & -5.65 & -6.02 & Lipid metabolic process \\
\hline Baiap211 & $\begin{array}{l}\text { BAI1-associated protein } \\
\text { 2-like } 1\end{array}$ & -2.25 & -3.82 & -3.40 & -3.74 & \\
\hline $\mathrm{C} 3$ & Complement component 3 & -3.32 & -5.79 & -7.26 & -3.63 & Signal transduction \\
\hline $\mathrm{C} 4 \mathrm{~b}$ & Complement component 4B & -2.39 & -3.31 & -4.23 & -5.20 & Inflammatory response \\
\hline Ccbe1 & $\begin{array}{l}\text { Collagen and calcium } \\
\text { binding EGF domains } 1\end{array}$ & -2.52 & -7.10 & -8.16 & -4.00 & Phosphate transport \\
\hline Cfi & Complement factor I & -5.94 & -2.31 & -4.75 & -4.28 & Proteolysis \\
\hline Cldn1 & Claudin 1 & -2.01 & -4.58 & -3.63 & -4.55 & Cell adhesion \\
\hline $\mathrm{Cp}$ & Ceruloplasmin & -2.31 & -3.24 & -3.89 & -4.40 & Ion transport \\
\hline Cpb1 & Carboxypeptidase B1 & -2.45 & -8.04 & -8.28 & -7.08 & Proteolysis \\
\hline Cth & Cystathionase & -2.70 & -4.11 & -4.63 & -4.16 & Amino acid biosynthetic process \\
\hline Cyp11a1 & $\begin{array}{l}\text { Cytochrome P450, family } 11 \\
\text { subfamily A, polypeptide } 1\end{array}$ & -2.37 & -6.60 & -8.45 & -7.31 & Lipid metabolic process \\
\hline Cyp11b2 & $\begin{array}{l}\text { Cytochrome P450, family } 11 \text {, } \\
\text { subfamily B, polypeptide } 2\end{array}$ & -2.60 & -8.00 & -8.52 & -10.92 & Lipid metabolic process \\
\hline Cyp21a1 & $\begin{array}{l}\text { Cytochrome P450, family } 21 \text {, } \\
\text { subfamily A, polypeptide } 2\end{array}$ & -2.94 & -7.98 & -8.85 & -9.26 & Electron transport \\
\hline Dab2 & $\begin{array}{l}\text { Disabled homolog } 2 \text {, } \\
\text { mitogen-responsive phos- } \\
\text { phoprotein }\end{array}$ & -2.09 & -4.78 & -4.81 & -3.50 & Cell proliferation \\
\hline Ephx1 & Epoxide hydrolase 1, & -2.11 & -3.39 & -3.50 & -5.78 & Xenobiotic metabolic process \\
\hline
\end{tabular}


Table III. Continued.

\begin{tabular}{|c|c|c|c|c|c|c|}
\hline \multirow[b]{2}{*}{$\begin{array}{l}\text { Gene } \\
\text { symbol }\end{array}$} & \multirow[b]{2}{*}{ Description } & \multicolumn{4}{|c|}{ Gene expression ( $\log _{2}$ tumor/normal ratio) } & \multirow[b]{2}{*}{ Biological process } \\
\hline & & $13 \mathrm{~T} / 13 \mathrm{~N}$ & $15 \mathrm{~T} / 13 \mathrm{~N}$ & $17 \mathrm{~T} / 13 \mathrm{~N}$ & $\begin{array}{l}\text { Pheo/ } \\
\text { normal }\end{array}$ & \\
\hline Fbp1 & $\begin{array}{l}\text { Fructose-1,6-bisphos- } \\
\text { phatase } 1\end{array}$ & -4.55 & -3.04 & -5.59 & -3.58 & Carbohydrate metabolic process \\
\hline Fdx1 & Ferredoxin 1 , & -1.68 & -4.92 & -5.41 & -5.51 & Steroid metabolic process \\
\hline $\mathrm{Fdxr}$ & Ferredoxin reductase & -2.63 & -5.59 & -5.71 & -5.11 & Lipid metabolic process \\
\hline Fgg & $\begin{array}{l}\text { Fibrinogen } \gamma \text { chain, } \\
\text { transcript variant } \gamma \mathrm{A}\end{array}$ & -5.63 & -1.67 & -4.92 & -3.83 & Signal transduction \\
\hline Fmo2 & $\begin{array}{l}\text { Flavin containing } \\
\text { monooxygenase } 2 \\
\text { (non-functional) }\end{array}$ & -2.09 & -4.05 & -4.94 & -3.48 & Electron transport \\
\hline Fmo3 & $\begin{array}{l}\text { Flavin containing } \\
\text { monooxygenase } 3\end{array}$ & -4.03 & -6.19 & -5.74 & -3.60 & Electron transport \\
\hline Galm & Galactose mutarotase & -2.84 & -3.59 & -3.76 & -4.61 & Carbohydrate metabolic process \\
\hline Gata6 & GATA binding protein 6 & -2.36 & -4.96 & -5.60 & -5.41 & $\begin{array}{l}\text { Positive regulation of } \\
\text { transcription }\end{array}$ \\
\hline Gckr & Glucokinase regulator & -4.45 & -2.80 & -3.94 & -3.75 & Cell glucose homeostasis \\
\hline Gja1 & $\begin{array}{l}\text { Gap junction protein, } \\
\alpha 1,43 \mathrm{kDa}\end{array}$ & -2.20 & -4.26 & -4.26 & -4.24 & Transport \\
\hline Gsta3 & Glutathione S-transferase A3 & -2.30 & -4.07 & -6.29 & -9.05 & Metabolic process \\
\hline Hsd11b1 & $\begin{array}{l}\text { Hydroxysteroid (11ß) } \\
\text { dehydrogenase } 1\end{array}$ & -2.18 & -3.53 & -4.40 & -3.95 & Metabolic process \\
\hline Hsd3b1 & $\begin{array}{l}\text { Hydroxy- } \Delta \text {-5-steroid } \\
\text { dehydrogenase, } 3 ß \text { - and } \\
\text { steroid } \Delta \text {-isomerase } 1\end{array}$ & -2.70 & -6.67 & -8.14 & -11.81 & Steroid biosynthetic process \\
\hline Inmt & $\begin{array}{l}\text { Indolethylamine N- } \\
\text { methyltransferase }\end{array}$ & -3.51 & -3.56 & -5.86 & -3.36 & \\
\hline Kcnk3 & $\begin{array}{l}\text { Potassium channel, } \\
\text { subfamily K, member } 3\end{array}$ & -2.40 & -4.59 & -5.16 & -3.46 & Ion transport \\
\hline Kcnn2 & $\begin{array}{l}\text { Potassium intermediate/ } \\
\text { small conductance calcium- } \\
\text { activated channel, sub- } \\
\text { family } \mathrm{N} \text {, member } 2\end{array}$ & -1.87 & -6.01 & -7.75 & -4.25 & Ion transport \\
\hline Ly6d & $\begin{array}{l}\text { Lymphocyte antigen } 6 \\
\text { complex, locus D }\end{array}$ & -2.35 & -7.54 & -9.04 & -5.49 & Cell adhesion \\
\hline $\mathrm{Mc} 2 \mathrm{r}$ & Melanocortin 2 receptor & -2.54 & -6.00 & -6.44 & -5.29 & Signal transduction \\
\hline Mgst1 & $\begin{array}{l}\text { Microsomal glutathione } \\
\text { S-transferase } 1\end{array}$ & -2.11 & -5.55 & -6.29 & -7.98 & Glutathione metabolic process \\
\hline Mlxipl & MLX interacting protein-like & -1.75 & -4.33 & -5.82 & -5.18 & Regulation of transcription \\
\hline Mrap & $\begin{array}{l}\text { Melanocortin } 2 \text { receptor } \\
\text { accessory protein }\end{array}$ & -2.60 & -7.07 & -8.40 & -6.05 & \\
\hline $\mathrm{Nr} 0 \mathrm{~b} 1$ & $\begin{array}{l}\text { Nuclear receptor subfamily } 0 \text {, } \\
\text { group } \mathrm{B} \text {, member } 1\end{array}$ & -2.63 & -7.14 & -8.16 & -9.23 & Adrenal gland development \\
\hline $\mathrm{NrOb} 2$ & $\begin{array}{l}\text { Nuclear receptor subfamily } 0 \text {, } \\
\text { group B, member } 2\end{array}$ & -2.89 & -4.98 & -5.17 & -6.43 & Cholesterol metabolic process \\
\hline Nr1h4 & $\begin{array}{l}\text { Nuclear receptor subfamily } 1 \text {, } \\
\text { group } \mathrm{H} \text {, member } 4\end{array}$ & -2.74 & -4.58 & -6.70 & -6.93 & Transcription \\
\hline Nr5a1 & Nuclear receptor subfamily 5 & -2.24 & -4.95 & -5.14 & -5.45 & Transcription \\
\hline
\end{tabular}


Table III. Continued.

\begin{tabular}{|c|c|c|c|c|c|c|}
\hline \multirow[b]{2}{*}{$\begin{array}{l}\text { Gene } \\
\text { symbol }\end{array}$} & \multirow[b]{2}{*}{ Description } & \multicolumn{4}{|c|}{ Gene expression ( $\log _{2}$ tumor/normal ratio) } & \multirow[b]{2}{*}{ Biological process } \\
\hline & & $13 \mathrm{~T} / 13 \mathrm{~N}$ & $15 \mathrm{~T} / 13 \mathrm{~N}$ & $17 \mathrm{~T} / 13 \mathrm{~N}$ & $\begin{array}{l}\text { Pheo/ } \\
\text { normal }\end{array}$ & \\
\hline Pdgfra & $\begin{array}{l}\text { Platelet-derived growth } \\
\text { factor receptor } \alpha \text { polypeptide }\end{array}$ & -2.13 & -3.83 & -4.69 & -4.61 & Cell proliferation \\
\hline Prlr & Prolactin receptor & -2.36 & -4.45 & -4.63 & -3.46 & Steroid biosynthetic process \\
\hline Rgn & Regucalcin & -4.31 & -3.35 & -6.08 & -5.15 & \\
\hline Rnf43 & Ring finger protein 43 & -2.58 & -4.67 & -6.19 & -4.94 & \\
\hline Scarb1 & $\begin{array}{l}\text { Scavenger receptor class B, } \\
\text { member } 1\end{array}$ & -2.13 & -5.29 & -5.83 & -5.53 & Cholesterol metabolic process \\
\hline Sec1414 & SEC14-like 4 & -2.44 & -3.45 & -6.50 & -3.53 & Transport \\
\hline Slc37a2 & $\begin{array}{l}\text { Solute carrier family } 37 \text {, } \\
\text { member } 2\end{array}$ & -2.19 & -3.17 & -3.77 & -4.60 & Transport \\
\hline Soat1 & Sterol O-acyltransferase 1 & -2.72 & -4.95 & -5.38 & -4.39 & Lipid metabolic process \\
\hline Star & $\begin{array}{l}\text { Steroidogenic acute } \\
\text { regulator, nuclear gene } \\
\text { encoding mitochondrial } \\
\text { protein }\end{array}$ & -1.73 & -6.67 & -8.63 & -8.64 & Steroid biosynthetic process \\
\hline Steap4 & STEAP family member 4 & -1.68 & -2.51 & -3.96 & -3.50 & Electron transport \\
\hline Tbx3 & T-box 3 & -1.86 & -4.69 & -5.22 & -4.77 & Anti-apoptosis \\
\hline $\operatorname{Tcf} 21$ & Transcription factor 21 & -2.07 & -2.76 & -5.20 & -3.88 & Organ morphogenesis \\
\hline Tspan 12 & Tetraspanin 12 & -2.09 & -4.89 & -5.29 & -3.49 & \\
\hline Tst & Thiosulfate sulfurtransferase & -2.44 & -4.79 & -5.00 & -4.70 & Sulfate transport \\
\hline Wnt4 & $\begin{array}{l}\text { Wingless-type MMTV } \\
\text { integration site family, } \\
\text { member } 4\end{array}$ & -2.86 & -7.27 & -7.73 & -3.78 & $\begin{array}{l}\text { Multicellular organismal } \\
\text { development }\end{array}$ \\
\hline
\end{tabular}

Pheo, human pheochromocytoma; normal, human normal adrenal medulla.

human cancers (26). In hematoxylin and eosin-stained sections, mouse adrenal tumor was composed of undifferentiated cells with a large nucleus (Fig. 1M and N). From comparison of the gene expression profiles by hierarchical clustering, up- or down-regulated genes in mouse adrenal tumor were overall similar to those in human pheochromocytoma (Fig. 3), but the expression patterns of noradrenergic neuron-related genes in mouse adrenal tumor were dissimilar with those in human pheochromocytoma (Table I), indicating that the characterization of mouse adrenal tumor was similar to that of human adrenal neuroblastoma rather than pheochromacytoma. This transgenic mouse might be a useful model of undifferentiated and aggressive adrenal neuroblastoma.

Researchers are studying chemotherapy drugs in order to find an effective therapy for neuroblastoma. In chemotherapy for high-risk neuroblastoma, the following drugs are often used: cyclophosphamide, ifosfamide, cisplatin, carboplatin, vincristine, doxorubicin (DXR), melphalan, etoposide (VP-16), teniposide (VM-26), and topotecan. In this study, we found that the expression of DNA topoisomerase II (Topo II $\alpha$ ) mRNA in adrenal tumors of transgenic mice increased 120-150-fold compared to non-transgenic mice (data not shown); therefore, we investigated the antitumor effect for transgenic mice by DXR, which is an inhibitor of Topo II $\alpha$. As a result, i.v. administration of DXR could suppress tumor growth significantly (data not shown), corresponding with the prognostic results from DNA array; therefore, this mouse model would be a useful tool for the development of anticancer drugs of neuroblastoma.

\section{Acknowledgements}

This study was supported in part by a Grant-in-Aid for Scientific Research from the Ministry of Education, Culture, Sports, Science, and Technology of Japan, and by the Open Research Center Project.

\section{References}

1. Brodeur GM, Maris JM, Yamashiro DJ, Hogarty MD and White PS: Biology and genetics of human neuroblastomas. J Pediatr Hematol Oncol 19: 93-101, 1997.

2. Yamamoto K, Hanada R, Kikuchi A, et al: Spontaneous regression of localized neuroblastoma detected by mass screening. J Clin Oncol 16: 1265-1269, 1998.

3. Tischler AS: Pheochromocytoma and extra-adrenal paraganglioma: updates. Arch Pathol Lab Med 132: 1272-1284, 2008 .

4. Adler JT, Meyer-Rochow GY, Chen H, et al: Pheochromocytoma: current approaches and future directions. Oncologist 13: 779-793, 2008. 
5. Aguzzi A, Wagner EF, Williams RL and Courtneidge SA: Sympathetic hyperplasia and neuroblastomas in transgenic mice expressing polyoma middle T antigen. New Biol 2: 533-543, 1990.

6. Hammang JP, Baetge EE, Behringer RR, Brinster RL, Palmiter RD and Messing A: Immortalized retinal neurons derived from SV40 T-antigen-induced tumors in transgenic mice. Neuron 4: 775-782, 1990.

7. Helseth A, Siegal GP, Haug E and Bautch VL: Transgenic mice that develop pituitary tumors: a model for Cushing's disease. Am J Pathol 140: 1071-1080, 1992.

8. Suri C, Fung BP, Tischler AS and Chikaraishi DM: Catecholaminergic cell lines from the brain and adrenal glands of tyrosine hydroxylase-SV40 T antigen transgenic mice. J Neurosci 13 : 1280-1291, 1993.

9. Fung KM, Chikaraishi DM, Suri C, et al: Molecular phenotype of simian virus 40 large $\mathrm{T}$ antigen-induced primitive neuroectodermal tumors in four different lines of transgenic mice. Lab Invest 70: 114-124, 1994.

10. Schulz N, Propst F, Rosenberg MM, et al: Patterns of neoplasia in c-mos transgenic mice and their relevance to multiple endocrine neoplasia. Henry Ford Hosp Med J 40: 307-311, 1992.

11. Schulz N, Propst F, Rosenberg MP, et al: Pheochromocytomas and C-cell thyroid neoplasms in transgenic c-mos mice: a model for the human multiple endocrine neoplasia type 2 syndrome. Cancer Res 52: 450-455, 1992.

12. Smith-Hicks CL, Sizer KC, Powers JF, Tischler AS and Costantini F: C-cell hyperplasia, pheochromocytoma and sympathoadrenal malformation in a mouse model of multiple endocrine neoplasia type 2B. EMBO J 19: 612-622, 2000.

13. Williams BO, Schmitt EM, Remington L, et al: Extensive contribution of $\mathrm{Rb}$-deficient cells to adult chimeric mice with limited histopathological consequences. EMBO J 13: 4251-4259, 1994.

14. You MJ, Castrillon DH, Bastian BC, et al: Genetic analysis of Pten and Ink4a/Arf interactions in the suppression of tumorigenesis in mice. Proc Natl Acad Sci USA 99: 1455-1460, 2002.

15. Jacks T, Shih TS, Schmitt EM, Bronson RT, Bernards A and Weinberg RA: Tumour predisposition in mice heterozygous for a targeted mutation in Nf1. Nat Genet 7: 353-361, 1994.
16. Iwakura H, Ariyasu H, Kanamoto N, et al: Establishment of a novel neuroblastoma mouse model. Int J Oncol 33: 1195-1199, 2008.

17. Hattori Y and Maitani Y: Folate-linked nanoparticle-mediated suicide gene therapy in human prostate cancer and nasopharyngeal cancer with herpes simplex virus thymidine kinase. Cancer Gene Ther 12: 796-809, 2005.

18. Wong DL: Why is the adrenal adrenergic? Endocr Pathol 14: 25-36, 2003.

19. Tischler AS, Freund R, Carroll J, et al: Polyoma-induced neoplasms of the mouse adrenal medulla. Characterization of the tumors and establishment of cell lines. Lab Invest 68: 541-549, 1993.

20. Cheung IY, Feng Y, Gerald W and Cheung NK: Exploiting gene expression profiling to identify novel minimal residual disease markers of neuroblastoma. Clin Cancer Res 14: 7020-7027, 2008.

21. Moreno-Sanchez R, Rodriguez-Enriquez S, Marin-Hernandez A and Saavedra E: Energy metabolism in tumor cells. FEBS J 274: 1393-1418, 2007.

22. Nakata $\mathrm{H}$ and Kozasa T: Functional characterization of Galphao signaling through $\mathrm{G}$ protein-regulated inducer of neurite outgrowth 1. Mol Pharmacol 67: 695-702, 2005.

23. Hedborg F, Ohlsson R, Sandstedt B, Grimelius L, Hoehner JC and Pahlman S: IGF2 expression is a marker for paragaglionic/ SIF cell differentiation in neuroblastoma. Am J Pathol 146: 833-847, 1995.

24. Swerts K, De MB, Dhooge C, et al: Potential application of ELAVL4 real-time quantitative reverse transcription-PCR for detection of disseminated neuroblastoma cells. Clin Chem 52: 438-445, 2006.

25. Zhou J, Li J, Chen J, Liu Y, Gao W and Ding Y: Over-expression of $\mathrm{CDH} 22$ is associated with tumor progression in colorectal cancer. Tumour Biol 30: 130-140, 2009.

26. Deeb KK, Michalowska AM, Yoon CY, et al: Identification of an integrated SV40 T/t-antigen cancer signature in aggressive human breast, prostate, and lung carcinomas with poor prognosis. Cancer Res 67: 8065-8080, 2007. 